\title{
Contents / Matières
}

Introduction

Howard Alper, OC, FRSC

Can Science or Ethics Compromise Each Other

in Human Subject Research?

\section{Bernard M. Dickens}

La privatisation de la recherche biomédicale

au Canada : enjeux éthiques

Marie-Hélène Parizeau

The Governance of Health Care

Research Involving Human Subjects:

Reflections on Ethical Policy for Science Research

Michael McDonald

Old Copyright Law and New Technologies:

Canadian Copyright Reform in the Digital Age

Michael Geist

La xénotransplantation :

tour de force ou tour de cochon?

Thérèse Leroux

British Beef, Ontario Water and Dead Crows

\section{Colleen Clements}

Notes on Contributors /

Notices biographiques des conférenciers 
This page intentionally left blank 